\title{
SUSCEPTIBILITY OF THREE WHEAT CULTIVARS TO MITE INFESTATION AND SOME MITE CONTROL MEASUREMENTS IN WHEAT FIELDS AT SHARKIA GOVERNORATE
}

\author{
M. M. A. Ibraheem; H. E. Megahed and O. M. O. Mohamad \\ Plant Protection Research Insttitute, Dokki,Giza, Egypt.
}

\section{ABSTRACT}

The present study includes three points, i.e., wheat cultivar susceptibility, seasonal fluctuation of mite species, associated predators and evaluation of certain control materials against mites on wheat plants.

The susceptibility of the three wheat cultivars (Sakha 93, Giza 168 and Gemiza 9) to investigation of mite species Petrobia tritici Kandeel, El-Naggar and Mohamed and two spotted spider mite, Tetranychus urtica) was inspected during the two successive seasons of 05/06 and 06/07 at Zagazig district. The obtained results revealed that the Sakha 93 cultivar was more susceptible to $P$. tritici infestation. The relatively higher numbers ranging 9.37-11.26 and 2.142-8.18 mitelleaf were recorded for the two mite species during the two seasons, respectively. The relatively lower mean numbers ranged 4.47-5.37 and 1.76-4.47 mite/leaf were recorded on Giza 168, while the moderate numbers of 6.36-8.47 and 2.08-4.7 mite/leaf were recorded on Gemiza 9 cultivar for the two mite species during the two study seasons.

The yield of test cultivar was found in contrast with infestation levels, where the relatively lower yield ranging 3.68-4.0 g/plant was recorded for the more susceptible cultivar, Sakha 93; while the highest yield ranging 6.0-6.02 $\mathrm{g} /$ plant was recorded for the more tolerant cultivar, Gemiza 9 which infested by moderate number of mites.

The result of seasonal fluctuation of the mite species infested the three tested cultivars revealed that the population of $P$. tritici recorded 1-2 peaks during the two seasons with the highest mean numbers of 28.0 and 34.33 mite/leaf on Sakha 93 at the first weak of April during the two seasons, respectively. The two spotted spider mite recorded 3-4 peaks on the tested cultivars during the two seasons with highest peak of 26.0 mitelleaf on Sakha 93 at early-April during the first season. During the second season, the highest peak of 7.0 mite/leaf was recorded at the end of March on Gemiza 9.

The relatively higher total predators number ranging 7.33-11.67 and 3.0-6.33 individuals/plant were recorded in timing with the high number of phytophagous mites on tested cultivars during the first and second seasons, respectively.

As evaluation of toxicant materials results, the all tested materials reduced the numbers of mites significantly compared with control with highest reduction percentages recorded for the convention pesticides followed by plant extracts and other materials. 
Regarding to reduction percentages, three groups were conducted, the first ranging 78.84-96.55\% (pesticides), 70.94-88.23\% (plant extracts) and 45.24-69.93\% (bio-products) during the two study seasons. Therefore, it could be concluded that the plant extracts and bio-products can be used as control agents for mites IPM programs in wheat fields.

Keywords: Wheat cultivars, mite infestation, mite control measurements, wheat fields, Sharkia Governorate.

\section{INTRODUCTION}

Wheat is the most important cereal food crop for man and his animals in the world. The wheat plants liably to attack by serious pests, recently, wheat plants infested by serious phytophagous mite species in different wheat growing regions and cause huage damage, especially at mid and north of Delta. The brown wheat mite (Petrobia tritici Kandeel, El-Naggar and Mohamed) was recorded as the most dangerous mite species that infest wheat fields and other gramineae hosts in many world regions, i.e., rice in Iran and South Africa infested by P. lateens (Müller), Wang et al. (1994), Krid and Toit (1988), Noorbakhsh (1993) and Prinsloo (2001). Also, the garlic plants in Spain, Estal, et al. (1992). This species found harbored some weeds such as, Convolvulus spium, Faradji, (1995).

Ecological, biological and control studies of Petrobia sp. were carried out by many authors allover the world, Estal, et al. (1985); Hu et al. (1985); Laffi (1985); Jain and Yadav (1988); Noorbakhsh (1993); Wang et al. (1985); Song et al. (1996); Prinsloo (2001) and Sharma, et al. (2001).

As a result of excessive use of pesticides at last decades in controlling pests causes often fail to prove effective control and aggravate other problems, i.e., development of pest resistance to pesticides, target pests resurgence and the third problem is that of induced secondary pests out break for example this pest on wheat plants which not recorded in noticed numbers before the last four years in Egyptian wheat fields.

As investigation of wheat plants during 2004/05, the brown wheat mite found infesting wheat plants with relatively notice numbers especially Sakha 93 cultivar and cause particularly damage to infested plants.

So, this work aims to provide decision maker by certain information about host cultivars susceptibility, evaluation of some control materials especially that used against cereal aphids, the principal infestation symptoms, population occurrence and density of brown wheat mite and two spotted spider mites as major mites species on tested wheat cultivars.

\section{MATERIALS AND METHODS}

The present investigations were under taken to finish some information which might help in the establishment of accurate recommendation for integrated pest management against the phytophagous mite species indeciuous wheat fields and includes the following points: 


\section{1- Relative susceptibility of three wheat cultivars to brown wheat mite infestation} and its population fluctuation:

Field trials were conducted during wheat growing seasons of $2005-2006$ and $2006-2007$ at Zagazig region in Sharkia Governorate in wheat fields. The selected investigation area about two fedd. was cultivated by the three wheat cultivars, Sakha 93, Gemiza 9 and Giza 168 each presented four replicates, each about 1/4 fedd., sown at November, 18 and 26 during the first and the second seasons, respectively. The experimental plots were received recommend agricultural practices and kept out of chemical control. The treatments plots were planned as completely randomized block design. Weekly samples of 25 leaves/replicate. were inspected actually in the field using hand lens. The numbers of mature and immature stages of different mite species and associated predators were recorded from plants emergence till harvest, then the yield of each treatment was determined as weight of the grain per plant. The variance between mean of mite numbers on tested cultivars was deduced as $\mathrm{F}$ test and Duncan`s multiple rang 1955 using Costat computer program.

\section{2- Evaluation of certain compounds against mites:}

a) The experimental design:

The experimental area about half feddan cultivated by sakha 93 cultivar at November 18 and 26 during the two wheat growing seasons of 2005/2006 and $2006 / 2007$, respectively was divided to 48 plots each about $1 / 100$ fed. and arranged as completely randomized plot design presenting 15 treatments as tested compounds and control in three replicates for each.

\section{b) Used compounds:}

The recommended aphicides and certain alternative materials were used against mites at recommended rate/100 liter water as target or non target pests in wheat fields as follows:

1- Insecticides:

- Aphox, Primicarb $50 \%$ SG at rate of 50 gm.

- MTI 446, dinotrofuran $20 \%$ WP (neo-nicotinoid of nitroimino derivatives) at rate of $50 \mathrm{gm}$.

- Malathiomex, Malathion $57 \%$ EC at rate of $150 \mathrm{ml}$

- Marshal, Carbosulfan 25\% WP at rate of $150 \mathrm{gm}$

- Tokthion, Prothiofos $50 \%$ EC at rate of $200 \mathrm{ml}$

- Marsal $2.5 \%$ EC at rate of $25 \mathrm{ml}$.

\section{2- Alternatives:}

- Plant extracts: Neemex at $100 \mathrm{ml}$, natural (Soyabean oil) at $250 \mathrm{ml}$, Al kanze (Gogoba oil, Simmondsia shinensis link (Buxaceae) at $250 \mathrm{ml}$.

- Bio-products: Naturalis at $75 \mathrm{ml}$, Biofly at $100 \mathrm{ml}$ (Buvaria bassiana at $30 \times$ $10^{6} \mathrm{IU}$ ) and Bioclin at $175 \mathrm{gm}$ (mixture of Bucillus thuringinisis Kurstak 32000 B.T $400 \mathrm{gm}$ and B. bassiana $5 \times 10^{7} 300 \mathrm{gm}$ )

- Mineral oils: Chemisol at rat of $1000 \mathrm{ml}$

- Detergents: Detergent at $1000 \mathrm{ml}$ (agricultural Ministry product). 


\section{c) Sampling and application procedures:}

One spray was applied at march, 18 and 25 during 2005/2006 and 2006/2007 seasons, respectively. Knap sack motor sprayer (12 liter in size) was used in application. Samples of 10 leaves per replicate were chosen randomly and investigated just before and after 2, 5, 8, 11 and 14 days of application. The number of alive mites individuals were recorded.

d) Data analysis: Reduction percentages of mite numbers for treatments were calculated as Henderson and Tilton (1955) formula:

$$
\% \text { Reduction }=1-(\mathrm{A} / \mathrm{B} \times \mathrm{C} / \mathrm{D}) \times \mathbf{1 0 0}
$$

Where: $A=$ Numbers of mite in treatments after application

$\mathrm{B}=$ Numbers of mite in treatments before application

$\mathrm{C}=$ Numbers of mite in control before application

$\mathrm{D}=$ Numbers of mite in control after application

The obtained results subjected to variance analysis and Duncan's (1955) multiple range using Costat computer programs.

\section{RESULTS AND DISCUSSION}

\section{I- Susceptibility of the three wheat cultivars to mite infestation:}

The obtained results in Table 1 show that the three tested cultivars were infested with brown wheat mite, Petrobia tritici Kandeel, El-Naggar and Mohamed as new serious pest on wheat in Egypt and the two spotted spider mite, Tetranychus urtica during the two study seasons. Significant variation was found between seasonal mean numbers of $P$. tritici on tested cultivars $(\mathrm{P}<0.05)$. The results clear that the Sakha 93 cultivar was more susceptible to mite infestation, where the highest mean numbers of 11.26 and 9.37 individuals/leaf were recorded on this cultivar; followed by 8.47 and 6.36 individuals/leaf on Gemiza 9 cultivar, while the relatively lower mean numbers of 4.47 and 5.37 individual/leaf was recorded on Giza 168 cultivar which could be considered as a more tolerant cultivar during the two study seasons, respectively.

The two spotted spider mite infestation seemed to be as well as brown wheat mite trend, where the highest mean numbers of 8.18 and 2.142 individual/leaf on Sakha 93, while 4.7 and 2.08 individual/leaf were recorded on Gemiza 9 and 4.47 and 1.76 individual/leaf on Giza 168 cultivars during the two study seasons, respectively.

So, it could be noticed that the more susceptible cultivar based on mean mite number infested wheat plants was Sakha 93 followed by Gemiza 9, while Giza 168 was found less susceptible to infestation by the two mites species; that may be depend on the vegetative growth variation.

The brown wheat mite as a new serious pest infested wheat plants found cause particular damage for infested plants by sucking plant sap, resulted in mottling of the leaf tissue and gave a brown or brownish appearance on the infested plants at the previous recorded high numbers. These results found in disagree with those of Brooks et al. (2001) who reported that the infestation levels ranging 20-50 mite/leaf only considering as heavy infestation. 
Table 1: Mean numbers of two mite species, $P$. tritici and $T$. urticae and associated predators on three wheat cultivars at Zagazig district during 2005/2006 season.

\begin{tabular}{|c|c|c|c|c|c|c|c|c|c|}
\hline \multirow[b]{2}{*}{ Dates } & \multicolumn{3}{|c|}{ Sakha 93} & \multicolumn{3}{|c|}{ Gemiza 9} & \multicolumn{3}{|c|}{ Giza 168} \\
\hline & $\begin{array}{l}P . \\
\text { tritici }\end{array}$ & $\begin{array}{l}\text { T. } \\
\text { urticae }\end{array}$ & $\begin{array}{l}\text { Total } \\
\text { predators }\end{array}$ & $\begin{array}{l}P . \\
\text { tritici }\end{array}$ & $\begin{array}{l}\text { T. } \\
\text { urticae }\end{array}$ & $\begin{array}{l}\text { Total } \\
\text { predators }\end{array}$ & $\begin{array}{l}P . \\
\text { tritici }\end{array}$ & $\begin{array}{l}T . \\
\text { urticae }\end{array}$ & $\begin{array}{l}\text { Total } \\
\text { predators }\end{array}$ \\
\hline $7 / 12 / 05$ & 0 & 8.0 & 0 & 0 & 3.0 & 0 & 0 & 1.33 & 0 \\
\hline 13 & 0 & 15.0 & 4.0 & 0 & 4.0 & 0 & 0 & 4.67 & 0 \\
\hline 19 & 0 & 10.33 & 2.33 & 0 & 6.0 & 0 & 0 & 3.0 & 0.33 \\
\hline 26 & 0.33 & 2.67 & 1.33 & 0 & 11.76 & 1.33 & 0 & 3.0 & 0.67 \\
\hline $2 / 1 / 06$ & 0.67 & 5.67 & 3.0 & 0 & 8.33 & 2.67 & 0 & 7.33 & 0 \\
\hline 9 & 1.33 & 12.0 & 3.67 & 1.0 & 2.0 & 3.0 & 0 & 5.33 & 2.33 \\
\hline 17 & 4.67 & 6.0 & 1.0 & 1.33 & 1.0 & 2.33 & 1.0 & 4.0 & 3.0 \\
\hline 23 & 7.67 & 6.67 & 1.0 & 3.33 & 2.0 & 2.0 & 1.33 & 3.0 & 2.33 \\
\hline 29 & 9.0 & 3.67 & 2.67 & 8.67 & 2.0 & 4.0 & 2.33 & 2.0 & 1.67 \\
\hline $7 / 2 / 06$ & 13.0 & 2.33 & 3.33 & 4.0 & 6.33 & 2.0 & 4.67 & 4.67 & 2.33 \\
\hline 14 & 17.0 & 5.0 & 1.33 & 4.0 & 9.33 & 2.67 & 7.0 & 6.0 & 4.0 \\
\hline 20 & 19.67 & 5.0 & 1.67 & 12.0 & 3.67 & 3.0 & 3.67 & 1.67 & 3.33 \\
\hline 27 & 12.67 & 6.0 & 2.0 & 16.0 & 3.0 & 3.0 & 2.0 & 2.33 & 3.67 \\
\hline 6/3/06 & 10.33 & 7.33 & 3.0 & 19.67 & 5.33 & 6.33 & 5.0 & 3.0 & 2.0 \\
\hline 13 & 19.67 & 8.67 & 4.67 & 21.0 & 7.33 & 9.67 & 9.67 & 8.0 & 4.67 \\
\hline 19 & 21.67 & 11.67 & 6.0 & 23.0 & 9.0 & 11.67 & 13.33 & 11.67 & 7.33 \\
\hline 26 & 24.33 & 18.33 & 6.0 & 27.33 & 13.0 & 10.0 & 15.67 & 6.0 & 5.67 \\
\hline $3 / 4 / 06$ & 28.0 & 26.0 & 8.0 & 18.0 & 6.0 & 7.0 & 19.67 & 6.0 & 3.0 \\
\hline 10 & 20.0 & 20.0 & 10.33 & 12.0 & 2.0 & 3.0 & 8.0 & 3.0 & 2.67 \\
\hline 18 & 20.67 & 8.67 & 7.67 & 9.0 & 0 & 1.33 & 3.0 & 2.33 & 1.33 \\
\hline 24 & 10.67 & 4.0 & 3.0 & 3.0 & 0 & 0 & 2.0 & 0.67 & 0.67 \\
\hline $1 / 5 / 06$ & 6.33 & 1.0 & 2.0 & 3.0 & 0 & 0 & 0 & 0 & 0 \\
\hline Total & 247.68 & 194.0 & 78.0 & 186.33 & 104.99 & 75.0 & 98.34 & 89.0 & 51.0 \\
\hline Mean & 11.26 & $\begin{array}{l}8.18 \\
\end{array}$ & 3.45 & 8.47 & 4.77 & 3.41 & 4.47 & 4.045 & 2.32 \\
\hline $\begin{array}{l}\text { Yield } \\
\text { (g/plant) }\end{array}$ & 4.0 & & & 6.06 & & & 5.25 & & \\
\hline
\end{tabular}

In regarding to grain yield, the relatively lowest plant yield was recorded for Sakha 93 infested plots recording 4.0 and $3.68 \mathrm{~g} /$ plant followed by 6.0 and 6.02 $\mathrm{g} /$ plant for the less susceptible cultivar, Gemiza 9 during the two study seasons, respectively; these results clear the corresponding relation between the mean numbers of mites and the plants yield.

\section{Seasonal fluctuation of mites population and its associated natural enemies:}

The results given in Tables $(1 \& 2)$ show that the population of the two mites species on the infested wheat plants were varied in density and fluctuated with numbers of peaks differed from a mite species to another, as well as, cultivars variation.

\section{a) Brown wheat mite, Petrobia tritici:}

The obtained results show that the first onset of $P$. tritici on wheat plants was recorded at the end-December 2005 on Sakha 93, retarded two and three weeks on 
Table 2: Mean numbers of two mite species, $P$. tritici and $T$. urticae and associated predators on three wheat cultivars at Zagazig district during 2006/2007season.

\begin{tabular}{|c|c|c|c|c|c|c|c|c|c|}
\hline \multirow[b]{2}{*}{ Dates } & \multicolumn{3}{|c|}{ Sakha 93} & \multicolumn{3}{|c|}{ Gemiza 9} & \multicolumn{3}{|c|}{ Giza 168} \\
\hline & $\begin{array}{l}P . \\
\text { tritici }\end{array}$ & $\begin{array}{l}T . \\
\text { urticae }\end{array}$ & $\begin{array}{l}\text { Total } \\
\text { predators }\end{array}$ & $\begin{array}{l}P . \\
\text { tritici }\end{array}$ & $\begin{array}{l}T . \\
\text { urticae }\end{array}$ & $\begin{array}{l}\text { Total } \\
\text { predators }\end{array}$ & $\begin{array}{l}P . \\
\text { tritici }\end{array}$ & $\begin{array}{l}T . \\
\text { urticae }\end{array}$ & $\begin{array}{l}\text { Total } \\
\text { predators }\end{array}$ \\
\hline 20/12/05 & 0 & 1.0 & 0 & 0 & 1.33 & 0 & 0 & 0 & 0 \\
\hline 27 & 1.33 & 3.0 & 1.0 & 0.67 & 2.0 & 0.33 & 0.33 & 1.67 & 0 \\
\hline $3 / 1 / 07$ & 0.67 & 2.33 & 0.67 & 0.67 & 1.33 & 0 & 0.67 & 2.0 & 0.33 \\
\hline 10 & 0.67 & 1.67 & 0.33 & 0.33 & 2.67 & 0.33 & 0 & 0.33 & 0 \\
\hline 17 & 1.33 & 2.33 & 0.33 & 0.67 & 1.67 & 0.67 & 0.33 & 3.0 & 0.33 \\
\hline 24 & 1.67 & 4.0 & 0.67 & 1.33 & 0.67 & 0.67 & 0.67 & 2.0 & 0.67 \\
\hline 31 & 0.67 & 3.33 & 1.33 & 0.67 & 2.0 & 0.33 & 1.33 & 1.67 & 1.0 \\
\hline $7 / 2 / 07$ & 3.0 & 1.33 & 1.0 & 1.33 & 3.0 & 0.67 & 2.0 & 0.67 & 1.33 \\
\hline 14 & 4.33 & 0.67 & 0.67 & 3.67 & 4.67 & 1.33 & 2.0 & 2.0 & 0.67 \\
\hline 21 & 6.67 & 0.67 & 1.67 & 4.0 & 4.0 & 1.67 & 4.33 & 4.0 & 0.67 \\
\hline 28 & 6.67 & 1.33 & 2.0 & 7.33 & 2.0 & 2.0 & 4.67 & 6.33 & 1.33 \\
\hline $7 / 3 / 07$ & 9.33 & 2.33 & 2.0 & 7.67 & 1.33 & 1.33 & 5.67 & 3.0 & 2.0 \\
\hline 14 & 11.67 & 5.0 & 3.33 & 10.0 & 2.33 & 0.67 & 8.33 & 1.67 & 2.67 \\
\hline 21 & 18.0 & 3.0 & 4.0 & 10.33 & 5.33 & 1.67 & 11.0 & 0.67 & 1.33 \\
\hline 28 & 29.67 & 3.33 & 4.67 & 14.33 & 7.0 & 3.0 & 11.0 & 1.33 & 1.33 \\
\hline $4 / 4 / 07$ & 34.33 & 5.67 & 6.33 & 19.0 & 1.0 & 2.67 & 13.67 & 2.33 & 3.67 \\
\hline 11 & 28.0 & 2.0 & 2.67 & 22.0 & 0.33 & 0.33 & 15.0 & 2.67 & 1.67 \\
\hline 18 & 22.33 & 1.33 & 0.67 & 15.67 & 0.67 & 0.67 & 18.67 & 1.0 & 0.67 \\
\hline 25 & 13.0 & 0.67 & 0.67 & 11.0 & 0.33 & 0.33 & 9.0 & 0.33 & 1.33 \\
\hline $2 / 5 / 07$ & 3.0 & 0 & 1.0 & 2.0 & 0 & 0 & 3.33 & 0 & 0.33 \\
\hline 7 & 33.0 & 0 & 0 & 1.0 & 0 & 0 & 0.67 & 0 & 0 \\
\hline Total & 196.67 & 44.99 & 35.01 & $\begin{array}{l}133.6 \\
7\end{array}$ & 43.66 & 19.67 & $\begin{array}{l}112.6 \\
7\end{array}$ & 36.67 & 21.33 \\
\hline Mean & 9.37 & 2.142 & 1.67 & 6.36 & 2.08 & 0.94 & 5.37 & 1.746 & 1.02 \\
\hline $\begin{array}{l}\text { Yield } \\
\text { (g/plant) }\end{array}$ & 3.68 & & & 6.02 & & & 4.88 & & \\
\hline
\end{tabular}

Gemiza 9 and Giza 168 in relatively low numbers of $0.33,1.0$ and 1.0 individuals/leaf of the three cultivars, respectively. The population of the mite was fluctuated on the three tested cultivars recording two peaks during the first season, the highest peak numbers of 28.0, 27.33 and 19.67 mite/leaf recorded at the first week of April, end of March and early of April, on Sakha 93, Gemiza 9 and Giza 168 cultivars, respectively.

During the second season, two peaks were investigated on Sakha 93 and Gemiza 9 with highest numbers of 34.33 and 22.0 mite/leaf recorded at the first and the second weeks of April, respectively; while on Giza 168 only one peak of 18.67 mite/leaf was recorded at the third week of April.

These results found in agreement with those of Wang et al. (1985), Brooks, et al. (2001) and Mohamed (2004) who reported that the highest numbers of brown wheat mite recorded during the second half of March and first half of April on winter wheat. 


\section{b) Two spotted spider mites, Tetranychus urtica .}

The given data in Tables $(1 \& 2)$ clear that the infestation of T. urtica started early and in relatively higher numbers in comparable with $P$. tritici especially on Sakha 93 cultivar during the two study seasons.

The population of T. urtica recorded three peaks on Sakha 93 and Gemiza 9 cultivars with highest density of 26.0 and 13.0 mite/leaf recorded at early April and end of March, respectively; while four peaks were recorded on Giza 168 with highest one of 11.67 mite/leaf at mid-March during the first season. During the second season, relatively weak peaks of 5.67, 7.0 and 6.33 mite/leaf were recorded at earlyApril, end-March and end-February on Sakha 93, Gemiza 9 and Giza 168 plants, respectively.

Generally, the relatively higher peak was recorded on Sakha 93 during the first season and on Gemiza 9 during the second ones. So, the mite infestation was highest in the first season than the second ones. These results found in agreement with those of Mohamed (2004) who recorded that the infestation of two spotted spider mite occurred allover the growing season of wheat plants.

\section{c) The associated predators:}

The total numbers of predators were recorded as numbers of predator mites (Neothoria niloticaus Abou-Awad and El-Bagoury, Cyta latirostris Hermann, Cheyletus malaccensis Oudemans, Raphignathus evansi Zaher and Gomaa), predator thrips (Scolothrips sexmaculatus Perg), Coccinellid beetles, (Scyminus sp., Stethorns sp., Coccinella sp.), predator bug, (Orius sp.) and true spiders.

The presented data in Tables $(1 \& 2)$ show that the population of total predators was fluctuated and recorded three peaks on different cultivars during the two study seasons except Sakha 93 during the second season. The highest peaks of 10.33, 11.67 and 7.33 individuals/plants recorded at mid-April, third week of March during the first season, while during the second one were 6.33, 3.0 and 3.67 individuals/plant recorded at early-April, late-March and early-April on Sakha 93, Gemiza 9 and Giza 168 cultivars, respectively.

Generally, the relatively high numbers of predators were inspected in timing with the high numbers of phytophagus mits on tested cultivars during the investigated seasons with relatively high numbers at end March and early April. Also, the relatively high numbers were recorded on Gemiza 9 during the first season and on Sakha 93 cultivars during the second ones. These results found in agreement with those of El-heneidy and Attia (1989) who reported that the numbers of predators in wheat fields increased gradually towards the end of the growing season and peaked during April.

\section{Efficiency of certain aphicides and alternative compounds against phytophagous mites infesting wheat plants:}

The tested materials were evaluated against mites on Sakha 93 cultivar which infested with higher population of mites, P. tritici and T. urtica. 
The results present in Table 3 indicate that the all tested materials reduced mite numbers on treated plants significantly than untreated ones $(\mathrm{P}<0.01)$.

Data in Table 3 show that the reduction percentages of tested compounds during 2005/2006 season could be arranged in three groups: The first ranging 92.94$96.55,78.84-86.61$ and $85.89-91.17 \%$ reduction as initial effect, mean residual and general effects, with highest initial and mean residual percentages for Rethion, highest general effect for Tokthion. The second group ranging 75.53-88.23, 70.94-77.64 and 72.66-82.91\% reduction as initial effect, mean residual and general effects with highest percentages for Malathion. The third group ranging 45.24-57.37, 58.1769.93 and 56.67-62.97\% reduction as initial effect, mean residual and general effects with highest percentages of initial and general effects for natural oil and mean residual for Biofly.

During the second season of 2006/2007 the reduction percentages were arranged in three groups as previous season: The first group ranging 88.0- 96.96, 84.09-91.21 and 90.52-93.7\% reduction as initial effect, mean residual and general effects, respectively; with highest percentages of initial for Rethion, while the highest residual and general effects were recorded for Tokthion. The second group ranging 76.44-85.85, 70.06-83.76 and 71.84-84.86\% reduction for the conducted topics with highest initial for Marsal, mean residual for Neemex and mean general effects for Malathion. The third group ranging 39.81-53.43, 67.24 - 68.03 and 58.68-66.26\% reduction as initial effect, mean residual and general effects for Biofly, while highest residual recorded for Detergent.

Generally, it could be summarized that the chemical pesticides recorded highest reduction percentages along the experimental trials followed by plant extracts, Neemex and natural oil (Soyabean oil), Gogoba extract (Al Kanze), detergent and Chemisol (mineral oil), while the bio-products, Biofly, Nutralis and Bioclin compounds had relatively moderate effects on mites. It could be comment that, such previous data was essential as database for integrated control programs in wheat fields, where the plant extracts, mineral oil and Detergent can be used as IPM programs agents against wheat pests.

Further studies concerning the interaction between mites, associated natural enemies and wheat plants are still requested to:

a) Estimate economic threshold levels of mite infestation in wheat fields in Egypt to avoid disturbance of the natural balance resulting from the expansion and miss use of pesticides.

b) Increase the role of bio control agents through augmentation and conservation of the natural enemies in wheat field.

So, such results can be take in consideration, where plant extracts provides a moderate efficiency against mites and were less toxic against natural enemies than chemical pesticides. Also, these materials already use against aphids as key pest for long time in wheat fields and affected aphid population significantly, Megahed et al. (2002).

Conclusively, therefore, it could be concluded that the plant extracts and bioproducts can be used as control agents for mites IPM programs in wheat fields. 


\section{REFERENCES}

Brooks, H. L.; R. A. Higgins and P. E. Sloderbeck (2001): Wheat pests management. Kansas State University, WWW at Http://www.ozentksu.edu.

Duncan, D. B. (1955): Multiple range and multiple F tests. Biometrics, 11: 1-42.

El-Heneidy, A. H. and A. A. Attia (1989): Evaluation of the role of parasitoids and predators associated with aphids in Egypt. Bull. Ent. Soc. Egypt. Econ. Ser, 17: 147- 187.

Estal, P. Del; M. Arroyo; E. Vinuela and F. Budia (1985): Pest mites of garlic in Spain. Anuales del Instituto Nacional de Investigaoins Agrarias Serie Agricota 28(sp No) 131-145.

Estal, P. Del; E. Vinuela; J. Jacas; V. Marco; A. Adan and F. Budia (1992). Evaluation of some pesticides efficacy on the garlic mite, Petrobia latens Muller (Acarina: Tetranychidae). Boletin de Sanidad vegetal Plagas (Espana), 18(2): $331-335$.

Faradji, F. (1995): Report of Tetranychina harti (Ewing) (Acari: Tetranychidae) on rice in Iran. Proceeding of the $12^{\text {th }}$ Iranian Plant Protection Congress, $2-7$ Sep. 1995 Karadj P, 79.

Henderson, D. F. and E. W. Tilton (1955): Tests with Acaricides against the brown wheat mite. J. Eco. Ent., 48: 157 - 161.

Hu, M.; S. Q. Li and F. Y. Liu (1987): Law of growth and decline on Petrobia latens and its integrated control. Insect-Knowlede, 24(4): $201-204$.

Jain, P. C. and C. P. S. Yadav (1988): New record of brown wheat mite, Petrobia latens (Muller) on coriander. Indian J. Ent., 50 (3): 396.

Krid, C. F. and F. D. Toit (1988): The Brown Wheat Mite. Farming in South Africa, G 8:2.

Laffi, F. (1985): Occurrence of Potrobia latens (Mueller) (Acarina: Tetranychidae) on Convolvulus sepium Infermation. Fitopatologico, 35(10): 35-37.

Megahed, H. A., M. M. A. Ibraheem, Shahinaz, A. Attia and A. H. El-Heneidy (2002): Evaluation of certain insecticides and alternative chemicals against cereal aphids in Egyptian wheat fields. Agric. Res. J., Suez Canal Univ.,1: 6972 .

Mohamed, O. M. O. (2004): Ecological and biological studies on some mites associated with field crops in new reclaimed areas at Sharkia Governorate. Ph.D. Fac. Agric. Al-Azahar Univ., (pp. 229).

Noorbakhsh, S. H. (1993): Population dynamic of brown wheat mite Petrobia latens (Muller) in western Chahar-Mahal and Bakhtiari Iran. Proceedings of the plant protection congress of Iran 28 Aug.- 2 Sep. 1993 Rasht P. 18.

Prinsloo, G. (2001): When must Petrobia latens a pest on wheat be sprayed wheat focus, South Africa, 19(5): $10-11$.

Sharma, A.; M. Sharma; R. B. Halliday; D. E. Walter; H. C. Proctor; R. A. Norton and M. S. Colloff (2001): Effect of nutrients and salinity on the incidence of Petrobia latens (Muller) (Prostigmata:Tetranychidae). Acarology: Proceedings of the $10^{\text {th }}$ International Congress of Acarology, 349-351. 
Song, Y. D.; Y. Song and Y. X. Wang (1996): Control of Petrobia latens Bull. Agric. Sci. and Tech., 1:27.

Wang, K. Q.; R. J. Han and J. H. Shi (1985): The occurrence of brown wheat mite on wheat in an arid area and methods of control. Application of Atomic, Energy, in Agriculture, Yuanzineng, Nongye, Yingyong, 1: $14-15$.

Wang, X. Y.; J. L. Wang and S. J. Li (1994): Study on the population dynamics and chemical control of Petrobia latens (Muller). Plant Protection, 20(3): 17 - 18.

\section{قابلية ثلاثة أصناف من القمح للإصابة بالاكاروسات وتقييم لبعض عناصر المبر المكافحة لها في حقول القمح في محافظة الثمابة بالاكرقية}

محمد محمد احمد إبراهيم - حمدي السعيد مجاهد ـ عمر محمد عمر محمد

معهد بحوث وقاية النباتات - دقي - محمد - جيزة

تضمنت هذه الدر اسة ثنلاث نقاط و هى در اسة حساسية ثلاثة أصناف من القمـح للإصـابة بالاكاروسـات

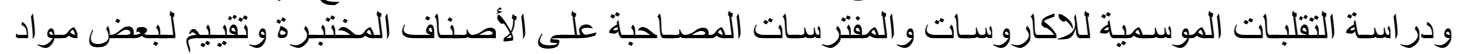
المكافحة على الاكاروسات في حقول القمح وجاءت التهات النتائج كما يلي:

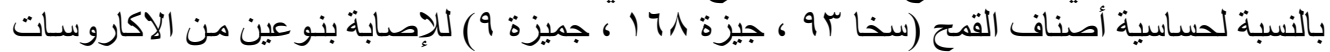

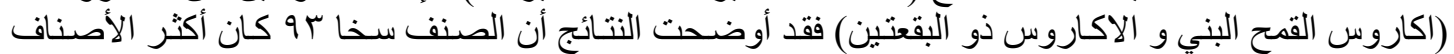

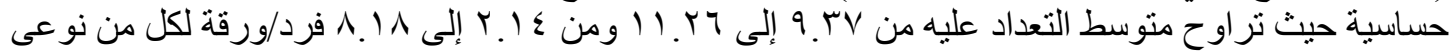

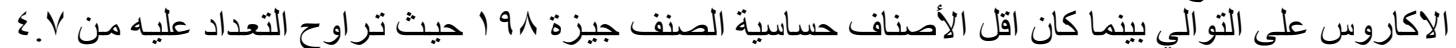

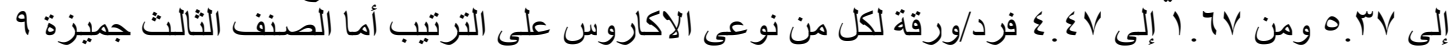

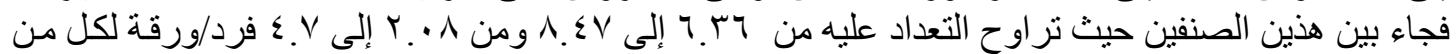
نوعى الاكاروس على التو الي.

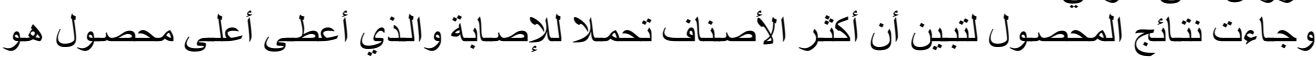

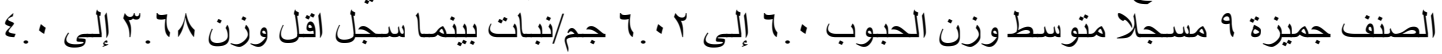

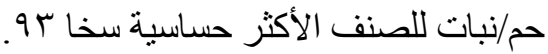

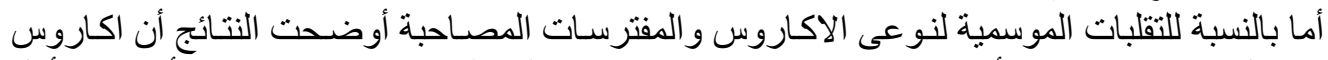

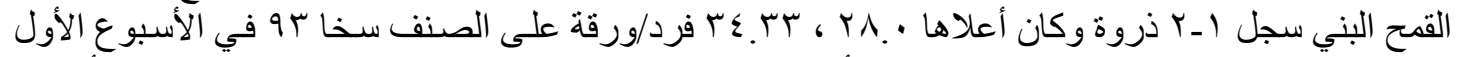

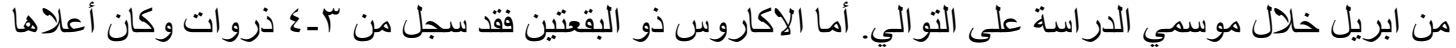

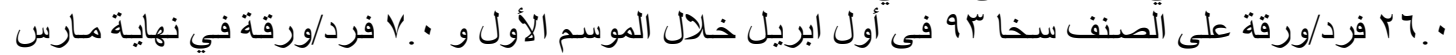

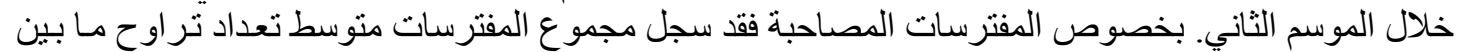

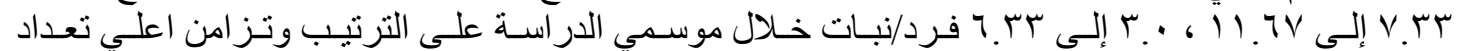
للمفترسات مع التعداد العالي للاكاروسات.

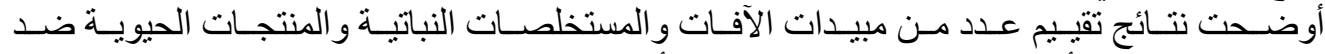

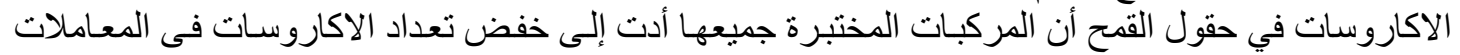

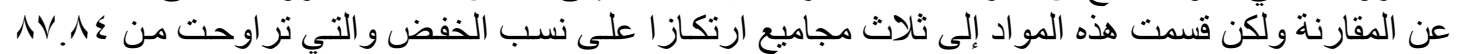

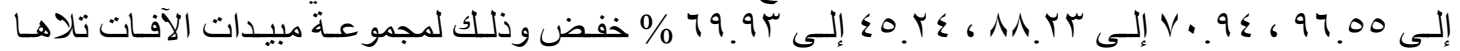

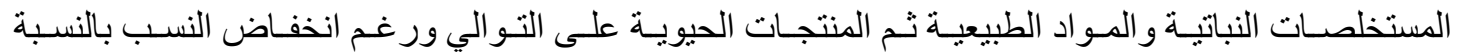

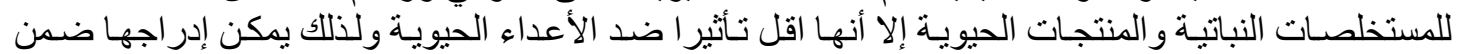
بر امج المكافحة المتكاملة للاكاروسات في حقول القماتح. 